УДК 616-001.3

РАЗРАБОТКА АЛГОРИТМОВ ПОМОЩИ ПОСТРАДАВШИМ, В УСЛОВИЯХ ЛОКАЛЬНЫХ КОНФЛИКТОВ, ПОЛУЧАЮЩИХ ПОМОЩЬ В БОЛЬНИЦАХ, ФУНКЦИОНИРУЮЩИХ В ЗОНЕ БОЕВЫХ ДЕЙСТВИЙ

Колесников А.Н., Плиев А.М., Слепушкин В.Д.

ГОО ВПО «Донецкий национальный медицинский университет им. М.Горького», г.Донецк, ДНР

Республиканский многопрофильный медицинский центр, г.Цхинвал, РЮО

Северо-Осетинская государственная медицинская академия (г.Владикавказ, РФ)

Резюме. В проведенном открытом, рандомизированном, многоцентровом, ретроспективном исследовании, достигнута цель в виде снижения рисков и шансов летальности у пострадавших, в условиях локальных конфликтов, получающих помощь в больницах, функционирующих в зоне боевых действий, за счет усовершенствования методов диагностики шока при различных видах травматического повреждения и тактики анестезиолого-реанимационной помощи на этапах сортировки и оказания помощи.

Ключевые слова: триаж, анестезиология, интенсивная терапия, транспортировка

\title{
DEVELOPMENT OF ALGORITHMS TO HELP VICTIMS IN CONDITIONS OF LOCAL CONFLICTS RECEIVING HELP IN HOSPITALS OPERATING IN THE COMBAT ZONE
}

Kolesnikov A.N., Pliev A.M., Slepushkin V.D.

GOO VPO «Donetsk National Medical University named after M. Gorky «, Donetsk, DPR

Republican Multidisciplinary Medical Center, Tskhinvali, Republic of South Ossetia

North Ossetian State Medical Academy (Vladikavkaz, RF)

Abstract. In an open, randomized, multicenter, retrospective study, the goal was achieved in the form of reducing the risks and chances of mortality in victims, in local conflicts, receiving assistance in hospitals operating in the war zone, by improving methods for diagnosing shock in various types of traumatic injury and tactics of anesthetic and resuscitation care at the stages of triage and care.

Key words: triage, anesthesiology, intensive care, transportation.

\section{АКТУАЛЬНОСТЬ}

Понятие (определение) - «ограниченные силы и средства» не подразумевает в себе неоказание помощи или отсутствие возможности, а применимо для военного времени, зоны локального террористического акта, военного конфликта или массового чрезвычайного происшествия, когда важно определить группу, которой не повредит отсутствие ИТ и доставка неспециализированным транспортом, и группу, которую нельзя транспортировать из-за риска смерти и необходимо оказать помощь немедленно, с учетом дальности (времени) транспортировки что и являлось целью исследования [1]. Дополнительную сложность исследования представляло то, что возможности больницы, функционирующей в зоне боевых действий, отличались от возможностей многопрофильной больницы. Оптимально использовать ограниченные возможности больницы с достижением максимального снижения шансов и рисков летального исхода у пострадавших являлось основным условием при разработке тактики интенсивной терапии [2].

\section{МАТЕРИАЛЫ И МЕТОДЫ}

Клиническая часть исследования проведена на основании изучения и ретроспективного анализа 1143 историй болезни пострадавших во время локальных военных конфликтов в г. Беслане 2002-2004 гг., в г. Цхинвале 1991-2008 г. и тактике оказания помощи в ДНР 2014-2018 гг. [3, 4]. 
В проводимом исследовании оценивались показатели пострадавших, полученные при первичном осмотре на месте сортировки (точка 1 - исходные витальные данные) и при поступлении в ЛПу (точка 2 - летальность) (І этап): - больницу, функционирующую в зоне боевых действий (г. Цхинвал, Республика Южная Осетия) [5]; - полноценно функционирующую больницу (г. Владикавказ, Республика Северная Осетия-Алания). Основным отличием пострадавших в группах, взятых для анализа было то, что у пострадавших из Беслана, доставленных в клинику СОГМА г. Владикавказа достоверно меньше было пациентов, которым не проводилась ИТ (6,4\% против 72,6\%), что отразилось на летальности в группах (1,2\% - Беслан и 13,7\% - Цхинвал) (решение 1 задачи исследования). Показатели основных индексов показали различие между группами в которых проводилась ИТ и не проводилась. Однако эти данные не давали ответы на вопросы исследования по поиску предикторов летальности и разработки критериев транспортабельности и адекватности проведения ИТ в больницах, функционирующих в зоне боевых действий. Более того, сравнение конфликтов в Беслане, Цхинвале, ДНР по оказанию помощи и маршрутам транспортировки, на наш взгляд, было не корректным (неэтичным), тем более качество оказания помощи в ЛПу, функционирующих в зоне боевых действий.

По данным обзора литературы, на современном этапе быстрота, неинвазивность и простота расчета являются главным требованием для применения в условиях локальных военных конфликтов и чрезвычайных происшествий [6]. Таким требованием удовлетворяют: систолическое АД, частота сердечных сокращений (ЧСС), показатель шкалы ком Глазго, вводимая поправка на возраст, и различные шкалы, использующие эти показатели (шоковый индекс (ШИ) - ЧСС/ сАД, реверсивный (обратный) шоковый индекс (рШИ) - сАД/ЧСС, ШИхВ - это шоковый индекс умноженный на возраст; обратный шоковый индекс деленный на возраст пациента - рШИ/В, ШИ/ШКГ - это шоковый индекс деленный на значение шкалы ком Глазго; шоковый индекс с учетом возрастного компонента и ШКГ - ШИхВ/ШКГ; рШИхШКГ-рШИ умноженный на ШКГ; рШИхШКГ деленный на возраст - рШИхШКГ/В) $[7,8]$.

Кроме того, на основе существующей идеи, мы усовершенствовали шкалу оценки тяжести состояния и транспортабельности: MGAP, которая включает В себя умножение следующих параметров: Mechanism - механизм травмы; Glasgow coma scale - шкала ком Глазго; Age - возраст; Pressure - систолическое АД, и представлена произведением четырех множителей: MGAP=мех-м

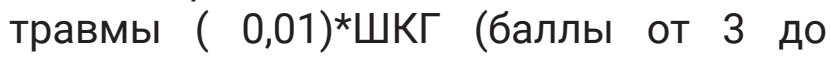
15)^возраст (годы)^систАД (мм рт.ст.)

\section{РЕЗУЛЬТАТЫ И ОБСУЖДЕНИЕ}

В проведенном диссертационном исследовании представлены пути решения актуальной задачи современной анестезиологии и реаниматологии - улучшении результатов лечения пациентов в больницах, функционирующих в непосредственной зоне боевых действий, связанной с выявленной проблемой «недосортировки». Разработана и внедрена тактика интенсивной терапии пострадавшим, включающая в себя необходимый объём оказания помощи, очередность транспортировки, направление транспортировки, условия транспортировки. Выявлены основные предикторы развития шока у пострадавших с различной локализацией поражения, с разработкой показаний к трансфузионной и инфузионной терапии на основании выявленных целевых показателей, характеризующих благоприятный исход и транспортабельность пациентов.

С учетом важности «золотого часа» при проведении ИТ, для анализа были выбраны данные именно при поступлении в больницы, функционирующие в зоне боевых действий (имеющие ограниченные ресурсы оказания помощи) до доставки 
в многопрофильное ЛПу, с целью выделения особенностей критериев транспортировки, маршрутизации (длительности/ дальности возможной транспортировки) и основных принципов сортировки и ИТ, что характеризовало в целом тактику интенсивной терапии у пострадавших. Уже имеющиеся ретроспективные данные из г. Владикавказ, позволили менять тактику ИТ при оказании помощи пострадавшим в г. Цхинвале и ДНР, поэтому исследование было частично проспективным. Однако глубокий статистический анализ сделан только сейчас.

Для получения статистически достоверных показателей, данные из клиник г. Цхинвал и г. Владикавказ были объединены (II этап).

Основную массу пациентов в данном исследовании составляли мужчины (68,3\%), в возрасте 18-38 лет (73,8\%), гражданские (мирные) жители (75,7\%), со временем доставки в клиники до 3 часов $(85,2 \%)$ с превалирование пулевых ранений (63,3\%) с общей летальностью 10,8\%. В общей выборке обращало на себя внимание то, что процент пострадавших, которым проводили терапию и не проводили ИТ разделился примерно поровну (42,7 против $57,3 \% \%)$, равно как и доставка специализированным или попутным транспортом (40,3 против 59,7\%). При обработке общего массива данных не было выявлено достоверных отличий в летальности, связанных с возрастом: 18-38 лет - 12,9\%, 3948 лет - 9,84\% и 49-58 лет - 11,02\%. Характер современного поражающего оружия, применяемого террористами (как показала практика контртеррористических операций, войны в Южной Осетии, ДНР и ЛНР) подразумевает большее использование мин и снарядов, с максимальным нанесением осколочных и взрывных травм. Так, в общем массиве данных, травмы связанные с минно-взрывным характером имели наибольшую летальность, которая составляла 22,9\%, осколочные и пулевые травмы - 10,9\% и сочетанные, множественные (комбинированные) - 9,8\%. При этом, также не было выявлено достоверных различий в показателях между группами по характеру травмы. Впечатляющие данные продемонстрировали показатели, указывающие на время транспортировки. Так, при транспортировке длительностью (дальностью) более 5 часов от момента получения травмы летальность составила $57 \%$, от 3 до 5 часов $-42,7 \%$ и до 3 часов - 6,9\%. Именно в этой группе данных наглядно видна и роль ИТ, которая снижает летальность, даже в группе более 5 часов на $52,2 \%$, от 3 до 5 часов на $52 \%$ и до 3 часов на 16,9\%. Вид транспортного средства оказывал незначительное влияние на показатели летальности, увеличивая ее при доставке несанитарным транспортом (попутный, «на броне» и др.) на 5,4\%. Принципиальным отличием являлось то, что при доставке санитарным транспортом ИТ не проводилась только в 1,7\% случаев, тогда как несанитарным транспортом - в 94,8\% случаев. То есть, либо ИТ не проводилась совсем, либо проводилась до отправки, обуславливая задержку транспортировки. Оценка пострадавших по полу и контингенту, носило описательный характер, и не дало достоверных отличий, как в показателях летальности между группами (мужчины $11,5 \%$, женщины 7,02\% и военнослужащие - 13,3\%), так и по основным показателям, взятым в исследование (решение 2 задачи исследования). Учитывая, что в нашем исследовании участвовали пациенты, объединенные термином «политравма», то обязательная оценка по этим шкалам была необходима. К сожалению, на момент проведения исследования, модифицированная военная шкала ISS (MAIS), еще не была внедрена. Мы проводили оценку по шкалам, вначале разделив пострадавших по характеру ранения. При пулевом ранении, в группе выживших, оценка по шкале AIS составляла $4,1 \pm 0,1$, ISS $14,2 \pm 0,5$, в группе умерших AIS $4,5 \pm 0,3$, ISS 16,8 $\pm 1,1$ - без статистической разницы. При минно-взрывной травме в группе выживших оценка по шкале AIS составляла $5,2 \pm 0,3$, ISS $17,9 \pm 1,1$, в груп-

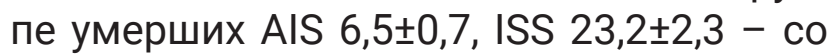
статистической разницей как между 
собой, так и с предыдущей группой. В группе «других ранений» в группе выживших оценка по шкале AIS составляла $3,7 \pm 0,2$, ISS $12,4 \pm 1,1$, в группе умерших AIS $2,3 \pm 0,3$, ISS 7,8 $\pm 1,2$ - со статистической разницей. Обращало на себя внимание несоответствие в оценке по шкалам с их трактовкой. Так в группе с пулевыми и прочими ранениями умерли пациенты, которые оценивались как легкие, а в группе с минно-взрывной травмой - как пограничные (стабильные). При общей оценке летальности во всех группах мы получили также несоответствие, когда в группе умерших пациентов оцен-

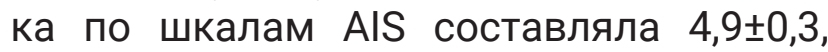
ISS $18,0 \pm 1,1$, а в группе выживших - AIS $4,3 \pm 0,1$, ISS $14,7 \pm 0,4$, что соответствовало легким травмам. Таким образом, было сделано два предварительных вывода: во-первых, оценка по шкалам AIS и ISS не обладает прогностической ценностью, а во-вторых, причиной летальности в группах пациентов были другие причины, которые предстояло выяснить. Оценка же по шкалам AIS и ISS, имеет описательный характер и может быть использована для иллюстрации количества повреждений у пациентов с различной локализацией. Так, у пациентов с травмой (ранением) конечностей оценка по шкалам AIS и ISS составляет AIS $3,2 \pm 0,1$, ISS 9,3 20,5 ; у пациентов с травмой (ранением) брюшной по-

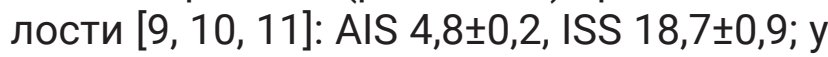
пациентов с травмой (ранением) грудной

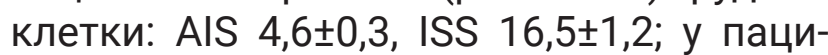
ентов с травмой (ранением) головы: AIS $3,9 \pm 0,1$, ISS $14,9 \pm 0,6$; у пациентов с сочетан-

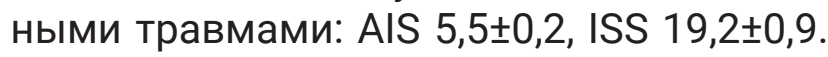

Были выявлены различия в летальности у групп пострадавших, анализируемых по принципу: все травмы (ранения) - 10,8\%, травмы (ранения) брюшной полости - 5,8\%; травмы (ранения) грудной клетки (полости)-14,8\%; травмы (ранения) головы - 18,4\%; травмы (ранения) конечностей - 2,9\% и сочетанные (комбинированные) травмы (ранения) - 18,3\%. Полученные данные позволили присвоить данным группам цвета, принятые при медицинской сортировке, для оценки очередности оказания помощи и транспортировке - первичная сортировка на пункте оказания помощи.

Одной из проблем оказания помощи во время военных конфликтов, как было выявлено из обзора литературы и первичного анализа материала, является проблема недосортировки, что затрудняет оказание помощи пациентам.

Так, в нашем исследовании, первичная сортировка на месте происшествия (поле боя) осуществлялась по стандартным системам сортировки ВПХ - Сорт и S.T.A.R.T, SIEVE, SORT, SALT, принятым как в России, так и во всем мире - доврачебный этап [12]. Во время которых, пациентам присваивается приоритет или цвет оказания помощи на месте событий, что сводится к оценке массивности кровопотери, стандартной схеме сердечно-легочной реанимации, согреванию, оценке симптома «белого пятна» (MARCH) и транспортировке на пункт оказания помощи.

Наш этап исследования касался, уже именно врачебной, специализированной помощи в больнице, функционирующей в зоне боевых действий с определением приоритетов. В отличие от существующих протоколов (например, CRAMS и др.), с целью решения проблемы «недосортировки» разработана система двойного цветового обозначения [3, 4]. Общепринятые цвета обозначают: группа приоритета I или «Красная группа» - пострадавшие в критическом состоянии, с тяжелыми повреждениями, требующими безотлагательной медицинской помощи в течение минут (60 минут - «золотой час» для доставки таких пострадавших в ближайшее медицинское учреждение); группа приоритета II или «Желтая группа» - пострадавшие с серьёзными повреждениями, которые не подвергают риску жизнь, конечности или зрение и состояние которых не ухудшится в течение нескольких часов; группа приоритета III или «Зеленая группа» - пострадавшие с незначительными повреждениями и нарушениями, ухудшение состояния которых 
маловероятно и группа приоритета IV или «Чёрная группа» - погибшие, или умирающие, получившие несовместимые с жизнью повреждения. Помощь таким пострадавшим не оказывается вообще либо имеет обезболивающий и смягчающий характер и оказывается в последнюю очередь.

Категорирование слишком большого количества жертв в «Красную группу» (чрезмерная сортировка) может привести к «распылению» медицинских ресурсов людям, которые не так сильно нуждаются в этом, пропуская (или задерживая оказание помощи) тяжело раненым [13, 14]. В проводимом исследовании примером такой группы являлись пациенты, анализируемые как «все ранения/травмы» - когда большинство из них вошли В «красную группу», что привело к необоснованной задержке транспортировки и оказанию помощи. Более того, имеет значение и направление транспортировки, которое может изменяться для пациентов с травмой грудной клетки и головы, когда требуется специализированная помощь.

Проведение аналитического статистического исследования позволило выделить и рекомендовать для использования этап первичной сортировки, с присвоением «цветов сортировки» пациентам по данным ретроспективнойоценкилетальности (табл. 1-3):

- травмы (ранения) головы - «Красный код» (табл.1);

- сочетанные (комбинированные) травмы (ранения) - «Красный код»(табл.1); - травмы (ранения) грудной клетки (полости) - «Красный код» (табл. 1);

- травмы (ранения) брюшной полости «Желтый код» (табл.2);

- травмы (ранения) конечностей - «Зеленый код» (табл.3)

- и все травмы (ранения) - без цвета, проведение стандартной сортировки.

Правильная сортировка, быстрая диагностика кровотечения (развития шока) и транспортировка являются главным трендом в терапии неотложных состояний. Поэтому на следующем этапе исследования мы статистически выявляли ценность используемых показателей для прогнозирования степени тяжести, летальности, в различных условиях: в зависимости от времени транспортировки, наличия специального транспорта, проведения или отсутствия ИТ в выделенных 6-ти группах пациентов.

Следует отметить, что при анализе, такой показатель, как частота дыхания, который имеет значение при первичной сортировке на поле боя [13], не выявил статистической значимости при прогнозировании.

При проведении многофакторного анализа показателей, оценивающих степень тяжести пациентов и степень шока (расчетные показатели) были выявлены показатели, которые являются предикторами летальности, целевые показатели при проведении ИТ, позволяющие предсказать положительный исход при транспортировке, а также дополнительные условия, влияющие на летальность пациентов в различных группах пострадавших.

Проведение статистического анализа, устанавливающего 99\% доверительный интервал, позволило выделить показатели для вторичной сортировки пациентов, с присвоением «цветового кода», соответствующего степени тяжести и являющегося показанием / противопоказанием для транспортировки, что в совокупности решало общую выявленную проблему «недосортировки».

Кроме того, в результате проведенного исследования были выявлены и систематизированы дополнительные показатели (табл.4), влияющие на летальность у пациентов в больницах, функционирующих в непосредственной зоне боевых действий, что дополнительно решало проблему «недосортировки».

Невзирая на выявленные особенности и границы показателей для каждого вида травмы, была предпринята 
попытка унифицировано оценить ранговость показателей, отсортированных по клиническим проявлениям и расчетным показателям шока (табл.5). Были выявлены клинически значимые пограничные величины, при которых существует необходимость (согласно, протоколов оказания помощи) проводить гемотрансфузию или массивную гемотрансфузию. Выявлены условия, при которых (при каких видах травмы и при каком значении индекса) отсутствует необходимость в проведении гемотрансфузии и/или агрессивной инфузионной терапии $[15,16]$.

С помощью полученных в исследовании данных методом бинарной логистической регрессии, изучались причинно-следственные связи, и устанавливалась роль прогностических факторов риска на исходы травм у пострадавших во время локальных боевых конфликтов: травма (ранение) (брюшной полости, грудной клетки, головы, конечности и сочетанная травма) [3, 4]. Построение прогностической модели проводили в два этапа. Первый этап - формирование базы данных анамнестических и клинических признаков пострадавших в условиях локальных конфликтов и создание статистической матрицы для последующего расчета регрессионного уравнения. Второй этап - непосредственный расчет и оценка логической адекватности (математической и клинической) всех полученных прогностических моделей, с целью выбора одной оптимальной. Основной задачей моделирования являлся прогноз исходов травм у пациентов, пострадавших в условиях локальных конфликтов и оценка адекватности проводимой интенсивной терапии с достижением «условий транспортабельности». По сути, такая модель является экспресс-прогнозом, так как строится на основании минимально достаточного числа наиболее простых и всегда исследуемых симптомов и синдромов, не требующих высокой квалификации врачебного персонала и применения специальных дополнительных инструментальных методов исследования. Поэтому, в качестве прогнозируемо- го показателя-отклика определены исходы у пациентов, пострадавших в зоне локальных конфликтов, с различными видами поражений (головы, брюшной полости, груди, конечностей и при сочетанной травме), в том числе и на фоне проводимой интенсивной терапии («благоприятный исход» - выживаемость пациентов и «неблагоприятный исход» - смерть пациентов). А в качестве признаков, предшествующих исходу травмы, и включаемых в модель как независимые факторы риска (причины), определена совокупность клинических признаков, достоверно связанных с исходами и определяемых у больных на ранних этапах оказания медицинской помощи. Решение задачи логистического регрессионного анализа нами было реализовано с помощью процедуры Logistic Regression Statistica 6.0. По итогам расчетов из нескольких вариантов моделей в окончательную прогностическую модель бинарной логистической регрессии включено 4 признака - фактора риска для развития ранних неблагоприятных исходов при поражении различных органов и систем у пострадавших в зоне военного конфликта, а именно - ШИ*возраст (X1), ШИ (X2), ШИ夫Возраст/ШКГ (Х3), ШИ/ШКГ (X4).

Анализируя полученные модели, мы можем отметить, что для развития неблагоприятного исхода при травме (ранении) головы наибольшее клиническое значение имеют 4 клинических признака: ШИ夫возраст, ШИ, ШИ^Возраст/ ШКГ, ШИ/ШКГ; для травмы (ранения) грудной клетки 1 признак: ШИ*Возраст/ ШКГ; для травмы (ранения) брюшной полости 1 признак: ШИ/ШКГ; для травмы (ранения) конечностей 1 признак: ШИ/ШКГ и для сочетанной травмы (ранения) 1 признак: ШИ夫Возраст/ШКГ. Полученные спецификационные таблицы позволили рассчитать диагностические характеристики для этих моделей, которые представлены в табл. 6. Как видно, все полученные диагностические характеристики достаточно высокие, поэтому этими математическими моделями можно 
пользоваться как диагности- шести алгоритмов тактики оказаческим тестом для прогнози- ния медицинской помощи в больрования исхода при ранении. ницах, функционирующих в зоне боТакимобразом, решениеосновнойцелиис- евых действий $[3,4,15]$ (рис. 1-6). следования резюмировалось созданием

Показатели, являющиеся противопоказанием для транспортировки без ИТ (требуется ИТ не позднее 60 мин) и стабилизации состояния

(99\% ДИ) - КРАСНАЯ ГРУППА

\begin{tabular}{|c|c|c|c|c|c|c|}
\hline Показатель & $\begin{array}{c}\text { Травма } \\
\text { (раненпи) } \\
\text { брюшной } \\
\text { полости } \\
\end{array}$ & $\begin{array}{c}\text { Травма } \\
\text { (ранення) } \\
\text { головы }\end{array}$ & $\begin{array}{l}\text { Травма } \\
\text { (ранения) } \\
\text { грудной } \\
\text { клетки } \\
\end{array}$ & $\begin{array}{c}\text { Травма } \\
\text { (раненшя) } \\
\text { конечностей }\end{array}$ & $\begin{array}{c}\text { Кохблни- } \\
\text { рованная } \\
\text { травма }\end{array}$ & $\begin{array}{c}\text { Все ранения } \\
\text { /травмы }\end{array}$ \\
\hline $\begin{array}{l}\text { С̆ст АЛ, } \\
\text { мм рт. ст. }\end{array}$ & $<67,4$ & $<66,9$ & $<76$ & $<86,6$ & $<66$ & $<62,3$ \\
\hline $\begin{array}{l}\text { ШКГ, } \\
\text { баллы } \\
\end{array}$ & $<9,7$ & $<7,3$ & $<8,7$ & $<12,4$ & $<7,5$ & $<7,2$ \\
\hline ши, ед. & $\geq 1,8$ & $\geq 1,96$ & $\geq 1,6$ & $\geq 1,03$ & $\geq 2,1$ & $\geq 2,3$ \\
\hline pШس'ШКГ, ед. & $<6,8$ & $<6,3$ & $<0$ & $<0$ & $<4,9$ & $<5,2$ \\
\hline 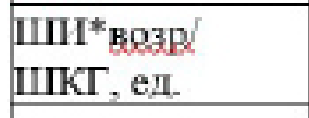 & $\geq 8,7$ & $\geq 14,3$ & $\geq 9,6$ & $\geq 0$ & $\geq 14,6$ & $\geq 17,06$ \\
\hline ШИ/ШКГ, ед. & $\geq 0,2$ & $\geq 0,4$ & $\geq 0,3$ & $\geq 0$ & $\geq 0,4$ & $\geq 0,45$ \\
\hline MGAP, ед. & $<208,6$ & $<175,8$ & $<213,2$ & $<0$ & $<175,2$ & $<159,8$ \\
\hline
\end{tabular}

Таблица 2

Целевые показатели (в т.ч. при проведении ИТ), характеризующие безопасность транспортировки (длительностью до 3 - 5 часов) (ДИ 99\%)-ЖЕЛТАЯ ГРУППА

\begin{tabular}{|c|c|c|c|c|c|c|}
\hline Показатель & $\begin{array}{c}\text { Травма } \\
\text { (ранения) } \\
\text { брюшной } \\
\text { полостI }\end{array}$ & $\begin{array}{c}\text { Травма } \\
\text { (ранення) } \\
\text { головы }\end{array}$ & $\begin{array}{c}\text { Травма } \\
\text { (ранения) } \\
\text { грудной } \\
\text { клетки } \\
\end{array}$ & $\begin{array}{c}\text { Травма } \\
\text { (ранения) } \\
\text { конечностей }\end{array}$ & $\begin{array}{c}\text { Комбиниро- } \\
\text { ванная } \\
\text { гравма }\end{array}$ & $\begin{array}{c}\text { Все } \\
\text { раненшія } \\
\text { /травмы }\end{array}$ \\
\hline पСC, уд в мІІн & $<105,2$ & $<99,7$ & $<110,6$ & $<99,2$ & $<111,7$ & $<106,2$ \\
\hline ШКГ, в балдах & $\geq 12,5$ & $\geq 11,2$ & $\geq 11,7$ & $\geq 12,8$ & $\geq 10.9$ & $\geq 11,9$ \\
\hline САД, мM рт, ст. & $\geq 99,5$ & $\geq 101,5$ & $\geq 93,4$ & $\geq 105,7$ & $\geq 92$ & $\geq 97,9$ \\
\hline ШІІ, ед. & $<1,09$ & $<1,02$ & $<1,2$ & $<1,07$ & $<1,3$ & $<1,13$ \\
\hline рШШ, ел. & $\geq 0,96$ & $\geq 1,04$ & $\geq 0,8$ & $\geq 1,1$ & $\geq 0,8$ & $\geq 0,95$ \\
\hline ВШН ШКГ, ед. & $\geq 12$ & $\geq 11,5$ & $\geq 10$ & $\geq 14,9$ & $\geq 9,2$ & $\geq 11,7$ \\
\hline $\begin{array}{l}\text { вШШ*ШКТ/ } \\
\text { в9зр, ед. }\end{array}$ & $\geq 0,3$ & $\geq 0,3$ & $\geq 0,3$ & $\geq 0,4$ & $\geq 0,3$ & $\geq 0,3$ \\
\hline ШI"возр, ед. & $<42$ & $<39,6$ & $<44,7$ & $<37,9$ & $<47,3$ & $<43,8$ \\
\hline $\begin{array}{l}\text { ШИ* возр/ШКГ, } \\
\text { ед. }\end{array}$ & $<3,6$ & $<3,9$ & $<4,2$ & $<2,9$ & $<4,7$ & $<3,9$ \\
\hline ШШ/ШКГ, ед. & $<0,09$ & $<0,09$ & $<0,1$ & $<0,08$ & $<0,13$ & $<0,1$ \\
\hline MGAP, ед. & $\geq 503,1$ & $\geq 450,3$ & $\geq 425,5$ & $\geq 585$ & $\geq 387.6$ & $\geq 470,9$ \\
\hline
\end{tabular}


Границы показателей (в Т.ч. при проведении ИТ), характеризующие пациентов, получивших несовместимые с жизнью повреждения (ДИ 99\%)ЧЕРНАЯ ГРУППА

\begin{tabular}{|c|c|c|c|c|c|c|}
\hline Показатель & $\begin{array}{c}\text { Tравма } \\
\text { (ранения) } \\
\text { брюшной } \\
\text { полості }\end{array}$ & $\begin{array}{c}\text { Травма } \\
\text { (раненшя) } \\
\text { годовы }\end{array}$ & $\begin{array}{c}\text { Травма } \\
\text { (раненгця) } \\
\text { грудной } \\
\text { клетки }\end{array}$ & $\begin{array}{c}\text { Травма } \\
\text { (ранення) } \\
\text { конечностей }\end{array}$ & $\begin{array}{l}\text { Комбдниро- } \\
\text { ванная } \\
\text { гравма }\end{array}$ & $\begin{array}{c}\text { Все } \\
\text { раненшя } \\
\text { /травмы }\end{array}$ \\
\hline ЧСС, уд в мин & $\geq 157,7$ & $\geq 143,6$ & $\geq 155,7$ & $\geq 158,5$ & $\geq 139,4$ & $\geq 134,3$ \\
\hline ШКГ, в баллах & $<4,1$ & $<3.9$ & $<3.5$ & $<4,2$ & $<5,3$ & $<5,6$ \\
\hline СAД, $\mathrm{MM}$ рт, $\mathrm{cT}$. & $<37,2$ & $<42,6$ & $<38,9$ & $<37,4$ & $<50,8$ & $<51,2$ \\
\hline Ши, ед. & $\geq 3,7$ & $\geq 3,2$ & $\geq 3,4$ & $\geq 3,7$ & $\geq 2,9$ & $\geq 2,8$ \\
\hline рШШ, ед. & $<0,2$ & $<0,32$ & $<0,2$ & $<0,2$ & $<0,4$ & $<0,4$ \\
\hline рШІ"ШКГ, ед. & $<0,5$ & $<0,8$ & $<0$ & $<0$ & 2,6 & $<2,9$ \\
\hline $\begin{array}{l}\text { рШШ*ШКГ/ } \\
\text { в.зв, ед. }\end{array}$ & $\geq 0,001$ & $\geq 0,07$ & $\geq 0$ & $\geq 0$ & $\geq 0,08$ & $\geq 0,09$ \\
\hline 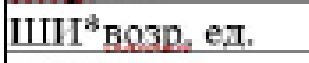 & $\geq 145,3$ & $\geq 125,5$ & $\geq 149.5$ & $\geq 138,7$ & $\geq 117,4$ & $\geq 109,9$ \\
\hline $\begin{array}{l}\text { Ш*вовр. } \\
\text { ШКГ, ед. }\end{array}$ & $\geq 27,4$ & $\geq 30,9$ & $\geq 35,05$ & $\geq 0$ & $\geq 28,6$ & $\geq 25,4$ \\
\hline ШИ/ШКГ, ед. & $\geq 0,8$ & $\geq 0,8$ & $\geq 0,8$ & $\geq 0$ & $\geq 0,7$ & $\geq 0,63$ \\
\hline MGAP, ед. & $<56,1$ & $<69,3$ & $<50,6$ & $<0$ & $<103,6$ & $<113,4$ \\
\hline
\end{tabular}

Таблица 4

Дополнительные показатели, влияющие на летальность у пострадавших

\begin{tabular}{|c|c|c|c|c|c|c|}
\hline Показатель & $\begin{array}{c}\text { Травма } \\
\text { (ранения) } \\
\text { брюшной } \\
\text { полости }\end{array}$ & $\begin{array}{c}\text { Травма } \\
\text { (раненгв) } \\
\text { головы }\end{array}$ & $\begin{array}{c}\text { Травма } \\
\text { (раненпя) } \\
\text { грудной } \\
\text { клетки }\end{array}$ & $\begin{array}{c}\text { Травма } \\
\text { (раненпя) } \\
\text { конечност } \\
\text { ей }\end{array}$ & $\begin{array}{c}\text { Комбгтнтрованн } \\
\text { ая травма }\end{array}$ & $\begin{array}{c}\text { Bсе } \\
\text { раненіц } \\
\text { /травмы }\end{array}$ \\
\hline $\begin{array}{c}\text { Возраст } \\
\text { паштентов }\end{array}$ & $\begin{array}{l}\text { 49-58 лет I } \\
\text { выте }\end{array}$ & нет & нет & нет & $\begin{array}{l}49-58 \text { дет и } \\
\text { выште }\end{array}$ & нет \\
\hline $\begin{array}{c}\text { Характер } \\
\text { травмы }\end{array}$ & $\begin{array}{c}\text { Мпнно- } \\
\text { взрывной } \\
\text { увеличивает } \\
\text { на } 9 \%\end{array}$ & $\begin{array}{c}\text { Пулевое } \\
\text { увелтгтвает } \\
\text { на } 13,7 \%\end{array}$ & \begin{tabular}{|c|} 
Мпнно- \\
взрывной \\
увелштпва \\
ет на \\
$11,6 \%$ \\
\end{tabular} & \begin{tabular}{|c|} 
Мннно- \\
взрывной \\
увелитгв-а \\
ет на \\
$10,6 \%$ \\
\end{tabular} & $\begin{array}{c}\text { Мпнно- } \\
\text { взрытвной } \\
\text { увелпчпвает на } \\
7,1 \%\end{array}$ & $\begin{array}{c}\text { Мннно- } \\
\text { взрывной } \\
\text { увеличпвает } \\
\text { на } 13,1 \%\end{array}$ \\
\hline \begin{tabular}{|} 
Tранспортпров \\
$\mathbf{\text { ка }}$
\end{tabular} & \begin{tabular}{|c|} 
несанитарны \\
м \\
гранспортом \\
повышает на \\
$8,2 \%$ \\
\end{tabular} & $\begin{array}{c}\text { несанштарны } \\
\text { м } \\
\text { транспортом } \\
\text { повытшет на } \\
12,5 \% \\
\end{array}$ & HeI & нет & $\begin{array}{c}\text { несанштарным } \\
\text { транспортом } \\
\text { повышает на } \\
15,4 \%\end{array}$ & \begin{tabular}{|c|} 
несанитарны \\
м \\
транспортом \\
повыштает на \\
$5,4 \%$ \\
\end{tabular} \\
\hline Длительностью & $\begin{array}{c}\text { бодее 5-1I } \\
\text { часов } \\
\text { повышенпе } \\
\text { летатьности } \\
\text { на } 51,4 \%\end{array}$ & $\begin{array}{c}\text { Более } 3 \\
\text { часов } \\
\text { повышенпе } \\
\text { летальности } \\
\text { на } 21,2 \% \\
\end{array}$ & \begin{tabular}{|c|} 
Более 3 \\
часов \\
повытеніт \\
е \\
петальност \\
п на $30-$ \\
$90 \%$ \\
\end{tabular} & $\begin{array}{c}\text { более 5-п } \\
\text { часов } \\
\text { повышени } \\
\mathrm{e} \\
\text { детальност } \\
\text { и на } 28,2 \%\end{array}$ & $\begin{array}{c}\text { Более } 3 \text { часов } \\
\text { повыпенпе } \\
\text { летальност на } \\
68,2 \%\end{array}$ & $\begin{array}{c}\text { Более } 3 \\
\text { часов } \\
\text { повышенпе } \\
\text { летальностп } \\
\text { на } 35 \text { - } \\
130 \%\end{array}$ \\
\hline $\begin{array}{c}\text { ИT } \\
\text { (отсутствует } \\
\text { возможность) }\end{array}$ & $\begin{array}{c}\text { повышение } \\
\text { летатьності } \\
\text { на } 9 \% \\
\end{array}$ & $\begin{array}{c}\text { повышенпе } \\
\text { летальностп } \\
\text { на } 15 \% \\
\end{array}$ & Hет & нет & $\begin{array}{c}\text { повышенше } \\
\text { летальности на } \\
15 \% \\
\end{array}$ & \begin{tabular}{|c|} 
Повышенше \\
летальності \\
на $27-50 \%$ \\
\end{tabular} \\
\hline
\end{tabular}


Таблица 5

Ранговость показателей шока в прогнозировании летальности, вероятности кровотечения, тактики ИТ (протокол массивной гемотрансфузии) (по данным оценки ОШ и клинически значимых пограничных величин)

\begin{tabular}{|c|c|c|c|c|c|c|c|c|c|}
\hline \multirow{2}{*}{$\begin{array}{c}\text { Вид } \\
\text { ранения }\end{array}$} & \multicolumn{9}{|c|}{ Индексы шока и ранговосдъ показателя (ОШі) } \\
\hline & ШII & $\begin{array}{l}\text { Ш }{ }^{*} \\
\mathrm{~B} 03 \mathrm{p}\end{array}$ & $\begin{array}{l}\text { ШII* } \\
\text { Bo3p' } \\
\text { ШIKГ }\end{array}$ & pLI & $\begin{array}{l}\text { RщLI/ } \\
\text { в03p. }\end{array}$ & $\begin{array}{l}\text { ШU' } \\
\text { ШК厂 }\end{array}$ & $\begin{array}{l}\text { рШس/ } \\
\text { ШК厂 }\end{array}$ & $\begin{array}{l}\text { вШШ* } \\
\text { ШКГ/ } \\
\text { Возр }\end{array}$ & $\begin{array}{l}\text { рШН* } \\
\text { ШКГ }\end{array}$ \\
\hline $\begin{array}{c}\text { Кшінш- } \\
\text { ческл } \\
\text { значшмые } \\
\text { граншщы }\end{array}$ & $\begin{array}{l}>1,0 \\
\leq 1,0\end{array}$ & $\begin{array}{l}>39,46 \\
\leq 39,46\end{array}$ & $2,63 \leq 2,63$ & $\begin{array}{l}\leq 0,96 \\
>0,96\end{array}$ & $\begin{array}{l}\leq 0,025 \\
>0,025\end{array}$ & $\begin{array}{l}>0,069 \\
\leq 0,069\end{array}$ & $\begin{array}{l}\leq 0,065 \\
>0,065\end{array}$ & $\begin{array}{l}\leq 0,38 \\
>0,38\end{array}$ & $\begin{array}{l}\leq 14,44 \\
>14,44\end{array}$ \\
\hline $\begin{array}{c}\text { Травма } \\
\text { брюшной } \\
\text { полоспі }\end{array}$ & 1 & 3 & 4 & 1 & 3 & - & 2 & 4 & - \\
\hline OШ & 10,7 & 4,7 & 4,4 & 10,7 & 4,7 & - & 7,8 & 4,4 & - \\
\hline $\begin{array}{c}\text { Tравма } \\
\text { (ранения) } \\
\text { головы }\end{array}$ & 1 & 3 & 2 & 1 & 4 & 5 & 7 & 2 & 6 \\
\hline OШ & 9,1 & 7,5 & 8,3 & 9,1 & 7,2 & 4,9 & 3,8 & 8,3 & 4,6 \\
\hline $\begin{array}{l}\text { Травма } \\
\text { Груш }\end{array}$ & - & 1 & 2 & - & 2 & - & 3 & 2 & - \\
\hline ОШ & - & 4,3 & 2,3 & - & 4,3 & - & 2,2 & 2,3 & - \\
\hline $\begin{array}{c}\text { Травма } \\
\text { қонечностей }\end{array}$ & 4 & 5 & 7 & 3 & 6 & 1 & 6 & 8 & 2 \\
\hline \begin{tabular}{|l|l} 
ОШ \\
\end{tabular} & 6,8 & 4,6 & 3,0 & 6,9 & 4,5 & 7,9 & 3,7 & 2,9 & 7,6 \\
\hline $\begin{array}{c}\text { Сочетанная } \\
\text { травма }\end{array}$ & 2 & 3 & 1 & 2 & 3 & - & 4 & 1 & - \\
\hline OII & 2,4 & 2,3 & 2,6 & 2,4 & 2,3 & $=$ & 1,7 & 2,6 & $=$ \\
\hline $\begin{array}{c}\text { Дтя всех } \\
\text { вщдов травм }\end{array}$ & 3 & 5 & 4 & 3 & 5 & 1 & 6 & 4 & 2 \\
\hline \begin{tabular}{l|l} 
OШ \\
\end{tabular} & 5,9 & 4,7 & 5,5 & 5,9 & 4,7 & 13,6 & 2,8 & 5,5 & 13,3 \\
\hline
\end{tabular}

Таблица 6

Диагностические характеристики моделей прогнозирования летального исхода при ранениях различной локализации. \%

\begin{tabular}{|c|c|c|c|c|c|}
\hline \multirow{2}{*}{$\begin{array}{c}\text { Дпагноспнеская } \\
\text { характерпстика } \\
\text { модеші }\end{array}$} & \multicolumn{5}{|c|}{ Локализация раненпя } \\
\hline & головы & $\begin{array}{l}\text { грудной } \\
\text { полості }\end{array}$ & $\begin{array}{l}\text { брюштной } \\
\text { полости }\end{array}$ & конечності & сочетанное \\
\hline $\begin{array}{l}\text { Диагностическая } \\
\text { тувствитетьность }\end{array}$ & 95,5 & 92,9 & 98,6 & 98,2 & 88,9 \\
\hline $\begin{array}{l}\text { Диагностическая } \\
\text { спешшфиность }\end{array}$ & 95,2 & 90,0 & 100,0 & 80,0 & 83,3 \\
\hline $\begin{array}{l}\text { Дпагностическая } \\
\text { эффективность }\end{array}$ & 95,3 & 91,4 & 99,3 & 89,1 & 86,1 \\
\hline $\begin{array}{l}\text { Прогноспическая } \\
\text { ценность отршщательного } \\
\text { результата (умереть) }\end{array}$ & 77,8 & 98,9 & 100,0 & 99,7 & 98,1 \\
\hline $\begin{array}{l}\text { Прогноспческая } \\
\text { ценность положительного } \\
\text { результата (вығжпть) }\end{array}$ & 99,2 & 56,3 & 76,9 & 40,0 & 43,9 \\
\hline
\end{tabular}




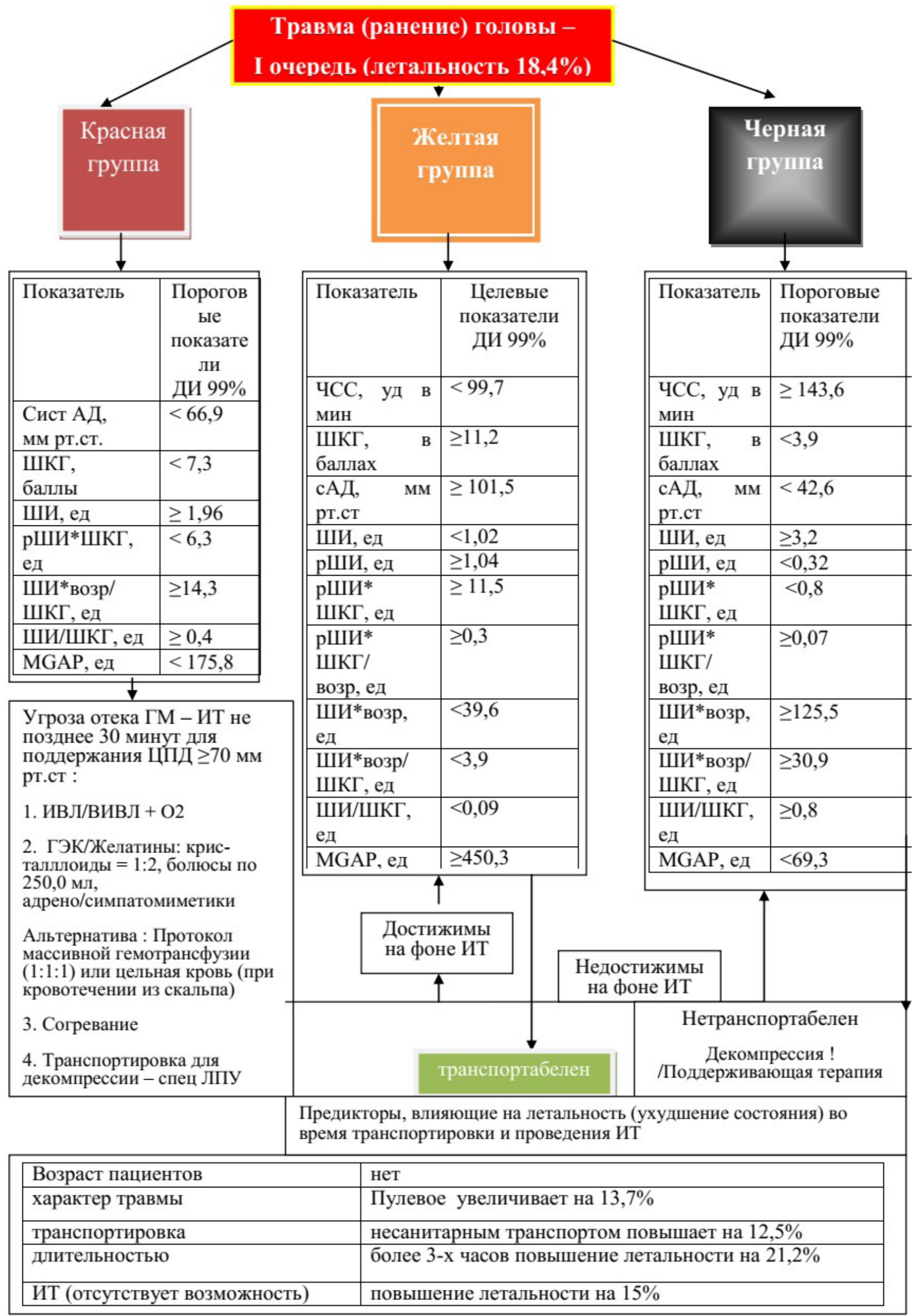

Рис. 1. Алгоритм 1. Тактика оказания медицинской помощи в больницах, функционирующих в зоне боевых действий пострадавшим с травмой (ранением) головы 


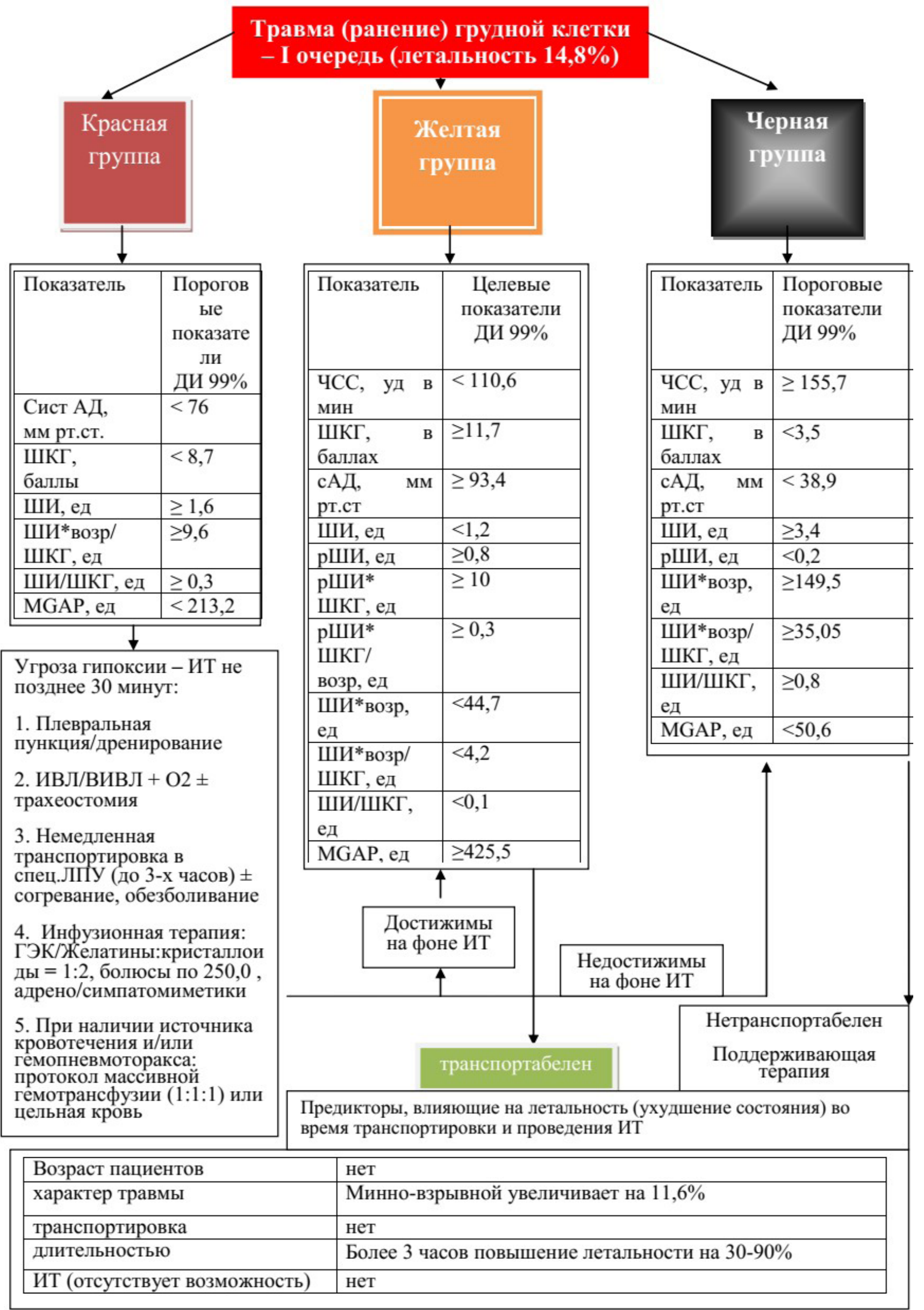

Рис. 2. Алгоритм 2. Тактика оказания медицинской помощи в больницах, функционирующих в зоне боевых действий пострадавшим с травмой (ранением) грудной 


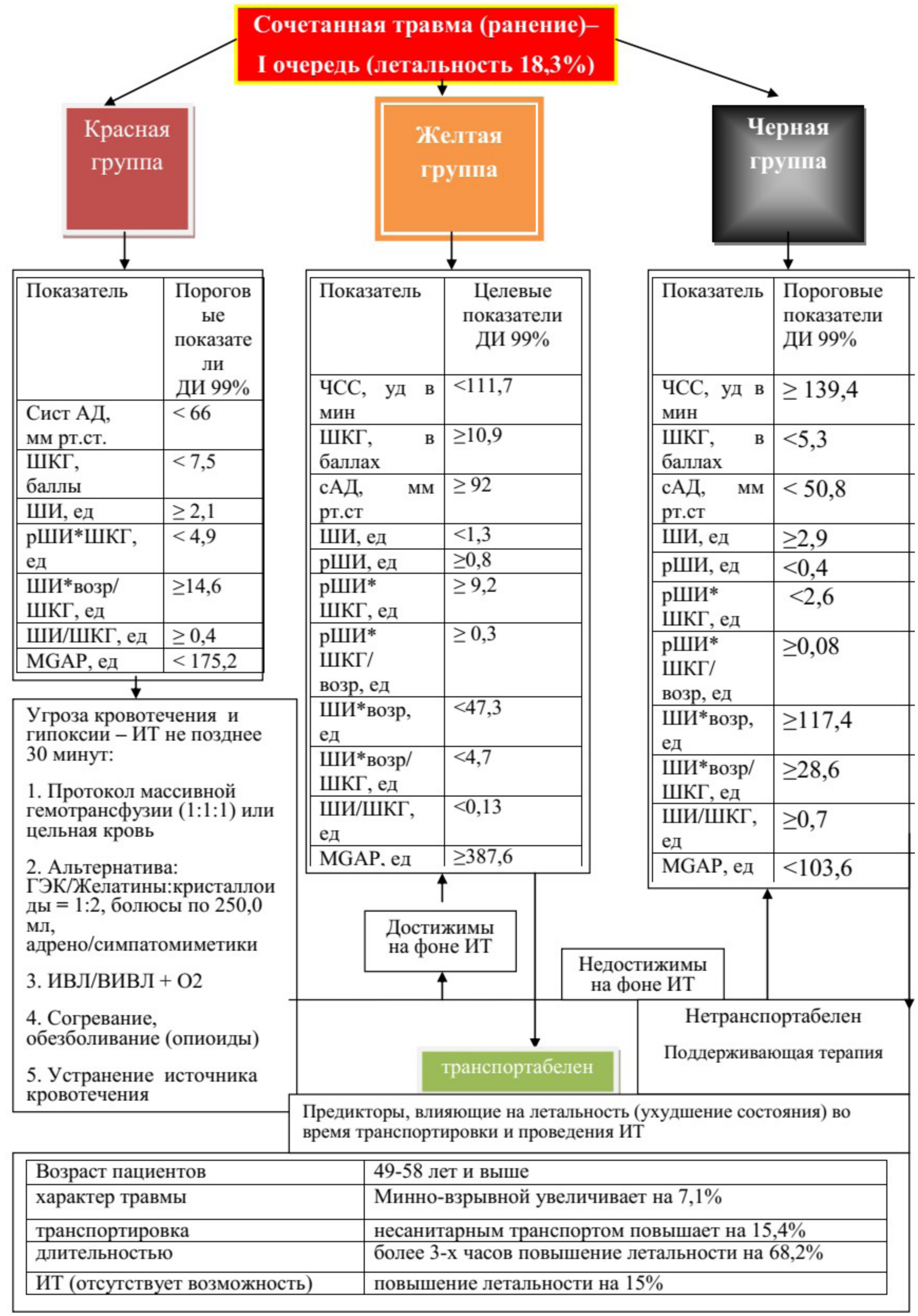

Рис. 3. Алгоритм 3. Тактика оказания медицинской помощи в больницах, функционирующих в зоне боевых действий пострадавшим с комбинированной (сочетанной) 


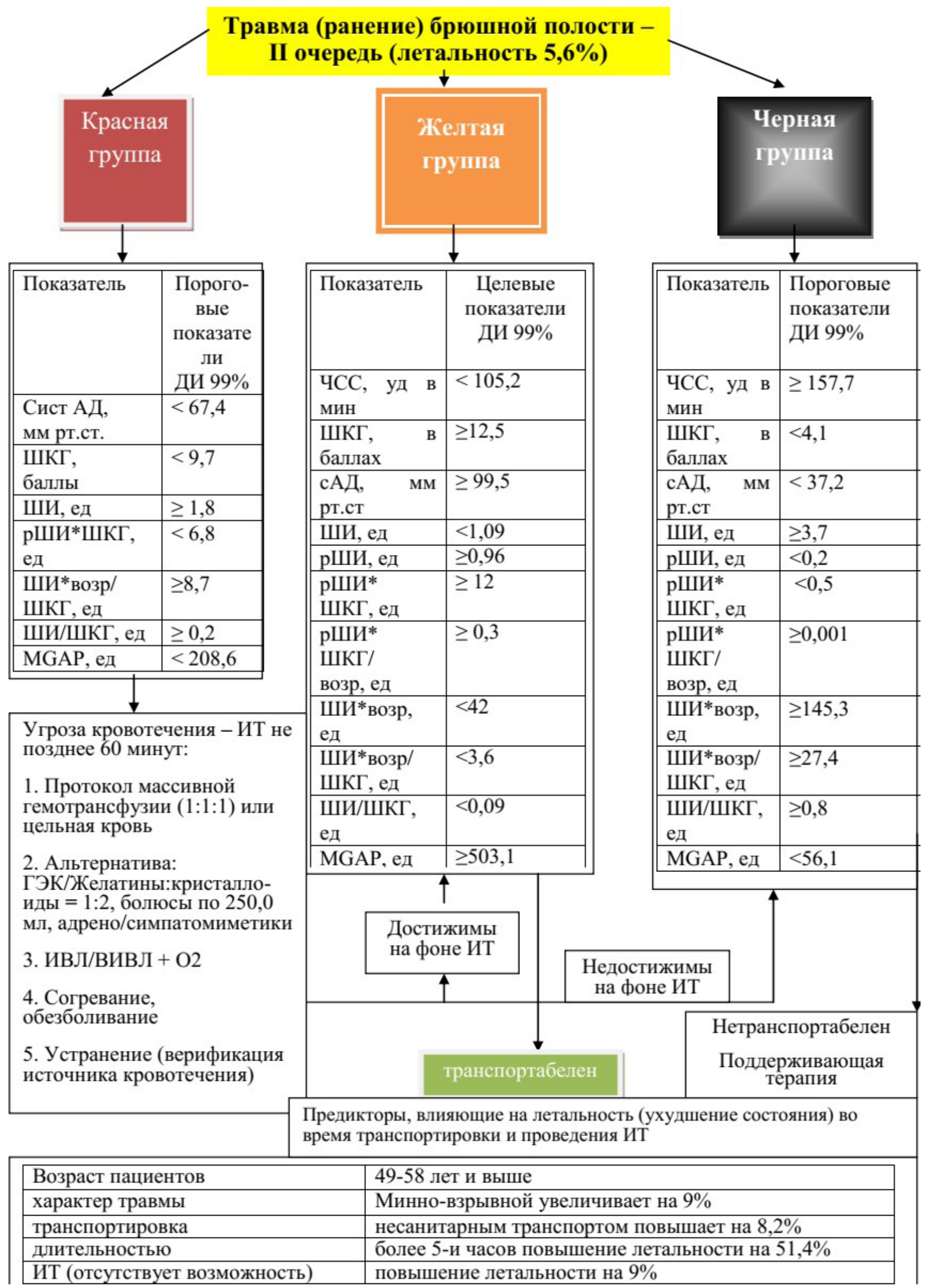

Рис. 4. Алгоритм 4. Тактика оказания медицинской помощи в больницах, функционирующих в зоне боевых действий пострадавшим с травмой (ранением) брюшной поло- 


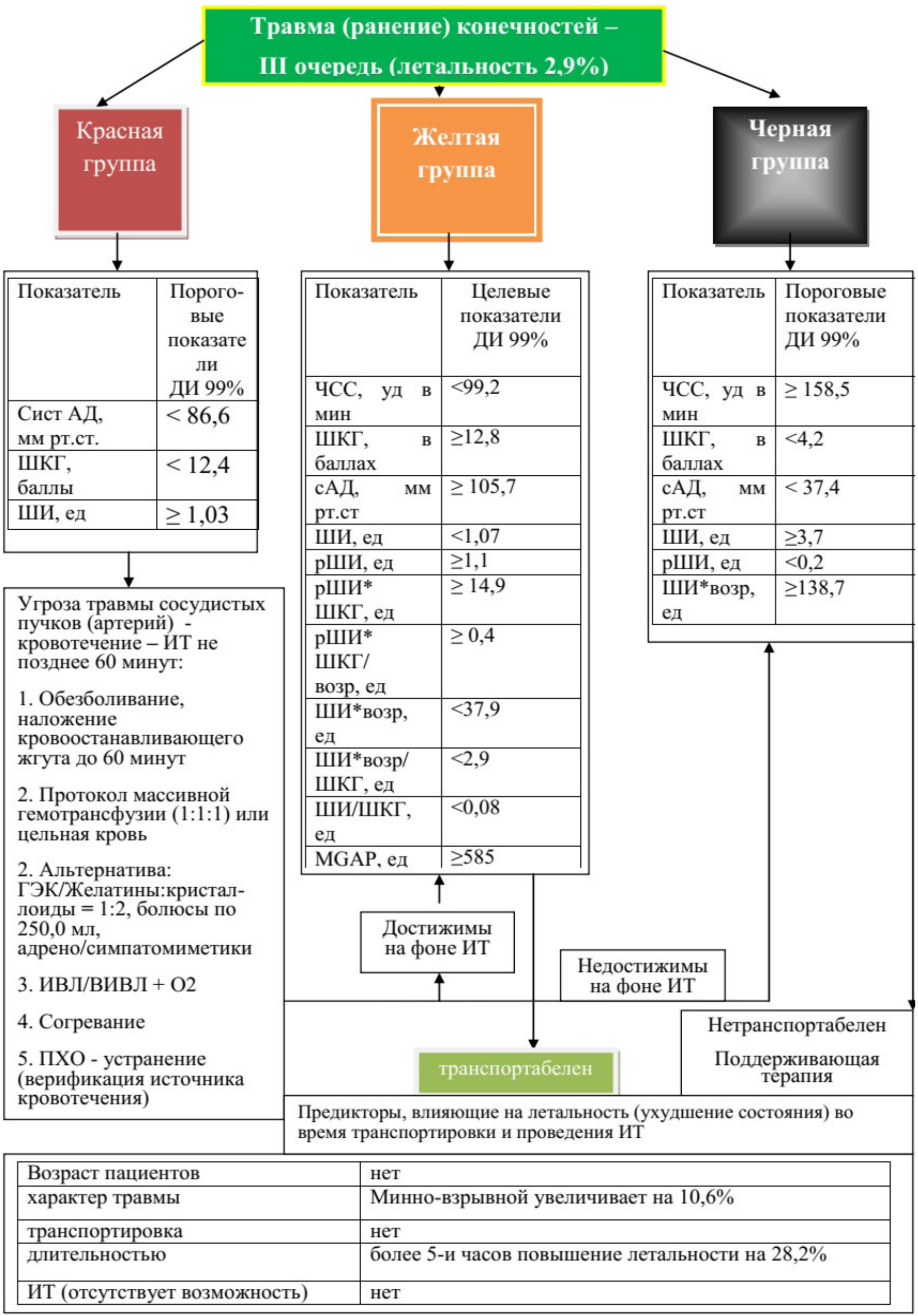

Рис. 5. Алгоритм 5. Тактика оказания медицинской помощи в больницах, функционирующих в зоне боевых действий пострадавшим с травмой (ранением) конечностей 


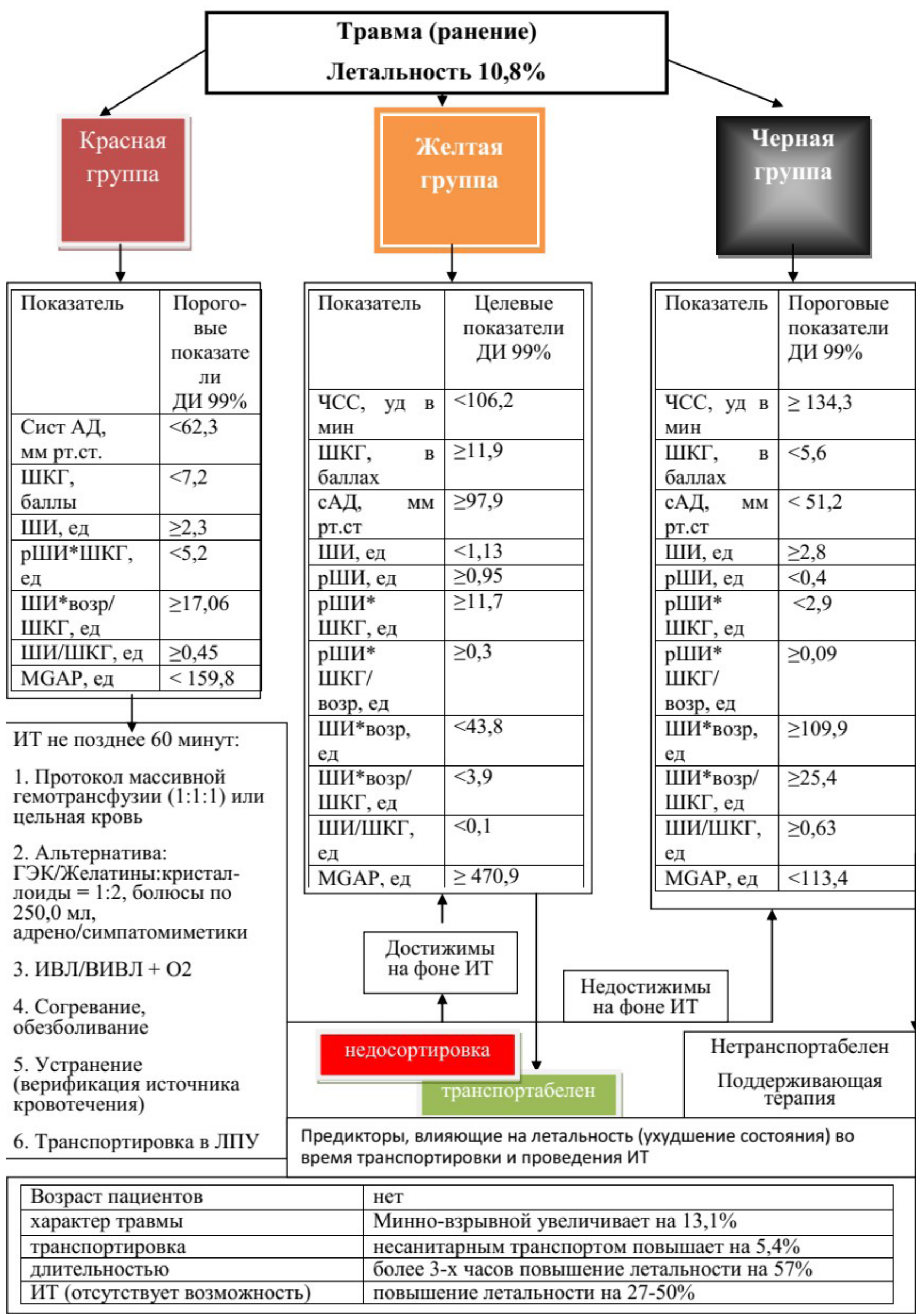

Рис. 6. Алгоритм 6. Тактика оказания медицинской помощи в больницах, функционирующих в зоне боевых действий пострадавшим с травмой (ранением) всех групп 


\section{СПИСОК ЛИТЕРАТУРЫ}

1. А.Н. Колесников, А.М. Плиев, О.С. Антропова. Алгоритмы оценки степени тяжести и терапии шока у пациентов с политравмой мирного и военного времени (обзор литературы). Материалы Международной научно-практической конференции, посвященной 80-летию Чеченского государственного университета. 2018. Грозный; 2018: 347-366. 2. Плиев А.М. Особенности анестезиолого-реанимационного обеспечения раненных и больных в условиях ограниченных ресурсов Республики Южная Осетия. Материалы научно-практической конференции хирургов и анестезиологов-реаниматологов Северо-Кавказского Федерального Округа с международным участием. 2013. Беслан; 2013: 56. 3. Плиев А.М. Тактика интенсивной терапии у пострадавшихпри локальных конфликтах в условиях ограниченных сил и средств:дис. канд. мед. наук. Донецк,2019.

4. Плиев А.М.. Тактика интенсивной терапии у пострадавших при локальных конфликтах в условиях ограниченных сил и средств: автореф. дис. канд. мед. наук. Донецк, 2019. 5. Плиев А.М. Опыт анестезиолого-реанимационной помощи во время грузино-осетинского конфликта. Материалы научно-практической конференции. 2015. Ставрополь; 2015. 6. А.Н. Колесников, А.М. Плиев, О.С. Антропова, Т.А. Мустафин. Политравма: все так знакомо и так неоднозначно, от дефиниции оценки степени тяжести до интенсивно терапии шока. Университетская Клиника. 2018; 2 (27): 60-68. 7. А.Н.Колесников., А.М.Плиев, Е.А.Кучеренко, О.С.Антропова, Т.А.Мустафин, Д.В.Горелов, Н.А.Колесникова. Оценка степени тяжести пациентов с политравмой по индексам шока. Архив клинической и экспериментальной медицины.2019; 1: 60-67. 8. А.Н. Колесников, А.М. Плиев, Е.А. Кучеренко. Оценка степени тяжести пациентов по индексам оценки шока. Материалы III Конгресса военных анестезиологов-реаниматоло- гов 2018. Санкт-Петербург; 2018: 41-44. 9. О.А.Шебзухов, В.Д.Слепушкин, А.М.Плиев. Диагностика повреждений органов брюшной полости на догоспитальном этапе. Известия Кабардино-Балкарского Университета. 2015; Т5, 3: 53-56. 10. А.М. Плиев, А.Н. Колесников, В.Д. Слепушкин. Определения повреждений внутренних органов при тупой травме живота в условиях ограниченных медицинских сил и средств при локальних военных конфликтах. Новые технологии в неотложной хирургии и анестезиологии-реаниматологии: материалы межрегиональной научно-практической конференции с международным участием. 2018. Владикавказ; 2018 : 47-49. 11. А.М.Плиев, О.А.Шебзухов, В.Д.Слепушкин, С.С.Айсханов, Т.Г.Габараев. Методики, повышающие возможности диагностикизакрытойтравмыживотавусловиях ограниченных сил и средств. Актуальные вопросы педиатрии, неонатологии, детской хирургии, анестезиологии и реаниматологии: материалы научно-практической корференции с международным участием. 2013. Ставрополь; 2013: 310-312. 12. В.Д.Слепушкин, А.М.Плиев, О.А. Шебзухов. Технологии лечения раненых на догоспитальном этапе, обеспечивающие раннюю реабилитацию. Аллергология и иммунология. 2014; Т.15, 2: 143. 13. В.Д.Слепушкин, А.М.Плиев, О.А. Шебзухов. Анализ уровня владения медицинским персоналом бригад скорой медицинской помощи и службы медицины катастроф навыками лечения острой дыхательной недостаточности. Медицина катостроф.2014; 2: 23-25. 14. В.Д.Слепушкин, В.З.Тотиков, А.М. Плиев. Опыт оказания хирургической и анестезиолого-реанимационной помощи примассовыхпоступленияхбольныхвклинику. Медицина катостроф. 2016; 3: 22-24. 15. Колесников А.Н., Плиев А.М., Слепушкин В.Д. и др. Тактика интенсивной терапии у пострадавших при локальных вооруженных конфликтах и террористических актах в условиях ограниченных сил и средств: 
Монография. Донецк-Цхинвал-Владикавказ: Типография ЮОГу; 2019: 268 с.

16. Плиев А.М. Слепушкин В.Д. Карданов А.X. Коррекция гиповолемического шока у раненных во время боевых действий в Республике Южная Осетия. Малоинвазивная и бескровная хирургия - реальность 21 века: материалы научно-практической конференции с международным участием. 2014.Владикавказ; 2014: 47-48. terapii u postradavshih pri lokal'nyh konfliktah vuslovijahogranichennyh silisredstv: avtoref. dis. kand. med. nauk [Intensive therapy tactics for victims of local conflicts in conditions of limited forces and resources: Cand.med. sci.diss.abs.]. Doneck, 2019 (in Russian). 5. Pliev A.M. Opyt anesteziologoreanimacionnoj pomoshhi vo vremja gruzino-osetinskogo konflikta [Experience of anesthetic and resuscitation care during the Georgian-Ossetian conflict]. Materialy

\section{REFERENCES}

1. A.N. Kolesnikov, A.M. Pliev, O.S. Antropova. Algoritmy ocenki stepeni tjazhesti i terapii shoka u pacientov s politravmoj mirnogo i voennogo vremeni (obzor literatury) [Algorithms for assessing the severity and therapy of shock in patients with peacetime and wartime polytrauma (literature review)]. Materialy Mezhdunarodnoj nauchnoprakticheskoj konferencii, posvjashhennoj 80-letiju Chechenskogo gosudarstvennogo universiteta [Materials of the International Scientific and Practical Conference dedicated to the 80th anniversary of the Chechen State University]. 2018. Groznyj; 2018: 347-366 (in Russian). 2. Pliev A.M. Osobennosti Anesteziologoreanimacionnogo obespechenija ranennyh i bol'nyh v uslovijah ogranichennyh resursov Respubliki Juzhnaja Osetija [Features of anesthetic and resuscitation support of the wounded and sick in the conditions of limited resources of the Republic of South Ossetia]. Materialy nauchno-prakticheskoj konferencii hirurgov i anesteziologov-reanimatologov Severo-Kavkazskogo Federal'nogo Okruga s mezhdunarodnym uchastiem [Materials of the scientific-practical conference of surgeons and anesthesiologistsresuscitators of the North Caucasus Federal District with international participation]. 2013. Beslan; 2013: 56 (in Russian). 3. Pliev A.M. Taktika intensivnoj terapii u postradavshih pri lokal'nyh konfliktah v uslovijah ogranichennyh sil i sredstv: dis... kand. med. nauk [Intensive therapy tactics for victims of local conflicts in conditions of limited forces and resources: Cand.med. sci.diss.abs.]. Doneck, 2019 (in Russian). 4. Pliev A.M. Taktika intensivnoj nauchno-prakticheskoj konferencii [Materials of the scientific and practical conference]. 2015. Stavropol'; 2015 (in Russian). 6. A.N. Kolesnikov, A.M. Pliev, O.S. Antropova, T.A. Mustafin. Politravma: vse tak znakomo i tak neodnoznachno, ot definicii ocenki stepeni tjazhesti do intensivno terapii shoka [Polytrauma: everything is so familiar and so ambiguous, from the definition of the severity assessment to the intensive therapy of shock]. Universitetskaja Klinika. 2018; 2 (27): 60-68 (in Russian). 7. A.N.Kolesnikov., A.M.Pliev, E.A.Kucherenko,O.S.Antropova,T.A.Mustafin, D.V.Gorelov, N.A.Kolesnikova. Ocenka stepeni tjazhesti pacientov s politravmoj po indeksam shoka [Assessment of the severity of patients with polytrauma by shock indices]. Arhiv klinicheskoj i jeksperimental'noj mediciny.2019; 1: 60-67 (in Russian). 8. A.N. Kolesnikov, A.M. Pliev, E.A. Kucherenko. Ocenka stepeni tjazhesti pacientov po indeksam ocenki shoka [Assessment of the severity of patients by shock assessment indices]. Materialy III Kongressa voennyh anesteziologovreanimatologov. [Materials of OR Congress of military anesthesiologists and resuscitators]. 2018. SanktPeterburg; 2018: 41-44 (in Russian). 9. O.A.Shebzuhov, V.D.Slepushkin, A.M.Pliev. Diagnostika povrezhdenij organov brjushnoj polosti na dogospital'nom jetape [Diagnosis of injuries of the abdominal organs at the prehospital stage]. Izvestija Kabardino-Balkarskogo Universiteta. 2015; T5, 3: 53-56 (in Russian). 10. A.M. Pliev, A.N. Kolesnikov, V.D. Slepushkin. Opredelenija povrezhdenij 
vnutrennih organov pri tupoj travme zhivota v uslovijah ogranichesnnyh medicinskih sil i sredstv pri lokal'nih voennyh konfliktah [Determination of injuries of internal organs in blunt trauma of the abdomen in conditions of limited medical forces and means in local military conflicts]. Novye tehnologii $v$ neotlozhnoj hirurgii i anesteziologii-reanimatologii: materialy mezhregional'noj nauchno-prakticheskoj konferencii s mezhdunarodnym uchastiem [New technologies in emergency surgery and anesthesiology-resuscitation: materials of an interregional scientific-practical conference with international participation]. 2018. Vladikavkaz; 2018: 47-49 (in Russian). 11. A.M.Pliev, O.A.Shebzuhov, V.D.Slepushkin, S.S.Ajshanov, T.G.Gabaraev. Metodiki, povyshajushhie vozmozhnosti diagnostiki zakrytoj travmy zhivota v uslovijah ogranichennyh sil i sredstv [Techniques that increase the possibility of diagnosing a closed abdominal trauma in conditions of limited forces and resources]. Aktual'nye voprosy pediatrii, neonatologii, detskoj hirurgii, anesteziologii i reanimatologii: materialy nauchno-prakticheskoj korferencii $\mathrm{s}$ mezhdunarodnym uchastiem [Topical issues of pediatrics, neonatology, pediatric surgery, anesthesiology and resuscitation: materials of scientific and practical conference with international participation]. 2013. Stavropol'; 2013: 310-312 (in Russian). 12. V.D.Slepushkin, A.M.Pliev, O.A.Shebzuhov. Tehnologii lechenija ranenyh nadogospital'nomjetape, obespechivajushhie rannjuju reabilitaciju [Technologies for treating the wounded at the prehospital stage, providing early rehabilitation]. Allergologija i immunologija. 2014; T.15, 2: 143 (in Russian). 13. V.D.Slepushkin, A.M.Pliev, O.A.Shebzuhov. Analiz urovnja vladenija medicinskim personalom brigad skoroj medicinskoj pomoshhi i sluzhby mediciny katastrof navykami lechenija ostroj dyhatel'noj nedostatochnosti [Analysis of the level of proficiency of medical personnel in emergency medical teams and emergency medicine services in the treatment of acute respiratory failure]. Medicina katostrof.2014; 2: 23-25 (in Russian). 14. V.D.Slepushkin, V.Z.Totikov, A.M.Pliev. Opyt okazanija hirurgicheskoj i anesteziologoreanimacionnoj pomoshhi pri massovyh postuplenijah bol'nyh $v$ kliniku [Experience in the provision of surgical and anesthetic and resuscitation care in case of mass admissions of patients to the clinic]. Medicina katostrof. 2016; 3: 22-24 (in Russian). 15. Kolesnikov A.N., Pliev A.M., Slepushkin V.D. i dr. Taktika intensivnoj terapii u postradavshih pri lokal'nyh vooruzhennyh konfliktah i terroristicheskih aktah v uslovijah ogranichennyh sil i sredstv [Intensive therapy tactics for victims of local armed conflicts and terrorist acts in conditions of limited forces and means]: Monografija. Doneck-Chinval-Vladikavkaz: Tipografija JuOGU; 2019: 268 (in Russian). 16. Pliev A.M. Slepushkin V.D. Kardanov A.H. Korrekcija gipovolemicheskogo shoka u ranennyh vo vremja boevyh dejstvij v Respublike Juzhnaja Osetija [Correction of hypovolemic shock in the wounded during the hostilities in the Republic of South Ossetia]. Maloinvazivnaja i beskrovnaja hirurgija - real'nost' 21 veka: materialy nauchno-prakticheskoj konferencii s mezhdunarodnym uchastiem [Minimally invasive and bloodless surgery is a reality of the 21 st century: materials of a scientificpractical conference with international participation]. 2014. Vladikavkaz;2014:47-48. 


\section{Сведения об авторах}

Колесников Андрей Николаевич;

Заведующий кафедрой анестезиологии, реаниматологии и неонатологии ГОО ВПО ДОННМУ ИМ.М.ГОРЬКОГО;

Доктор медицинских наук;

Профессор;

Адрес: пр. Ильича, 16, г. Донецк, 83003

Электронный адрес: akolesnikov1972@gmail.com

Плиев Александр Михайлович

Заместитель Председателя Парламента РЮО, председатель Комитета по социальной политике и здравоохранению;

Кандидат медицинских наук

Слепушкин Виталий Дмитриевич

Заведующий кафедрой анестезиологии и реаниматологии ФГБОУ ВО «Северо-

Осетинская государственная медицинская академия» Минздрава России, г. Владикавказ;

Доктор медицинских наук;

Заслуженный деятель науки РФ, профессор;

Адрес: 362019 Республика Северная Осетия-Алания, г.Владикавказ, ул.Пушкинская, 40 Электронный адрес: sogma@minzdrav.alania.gov.ru

ЭКСПЕРТНАЯ СИСТЕМА ДОГОСПИТАЛЬОГО ТРИАЖА DARTS

Авторский алгоритм медицинской сортировки, определения возможности транспортировки и предоставление рекомендаций о догоспитальной помощи пострадавшему.

Номер свидетельства: 2021664863

Google Play
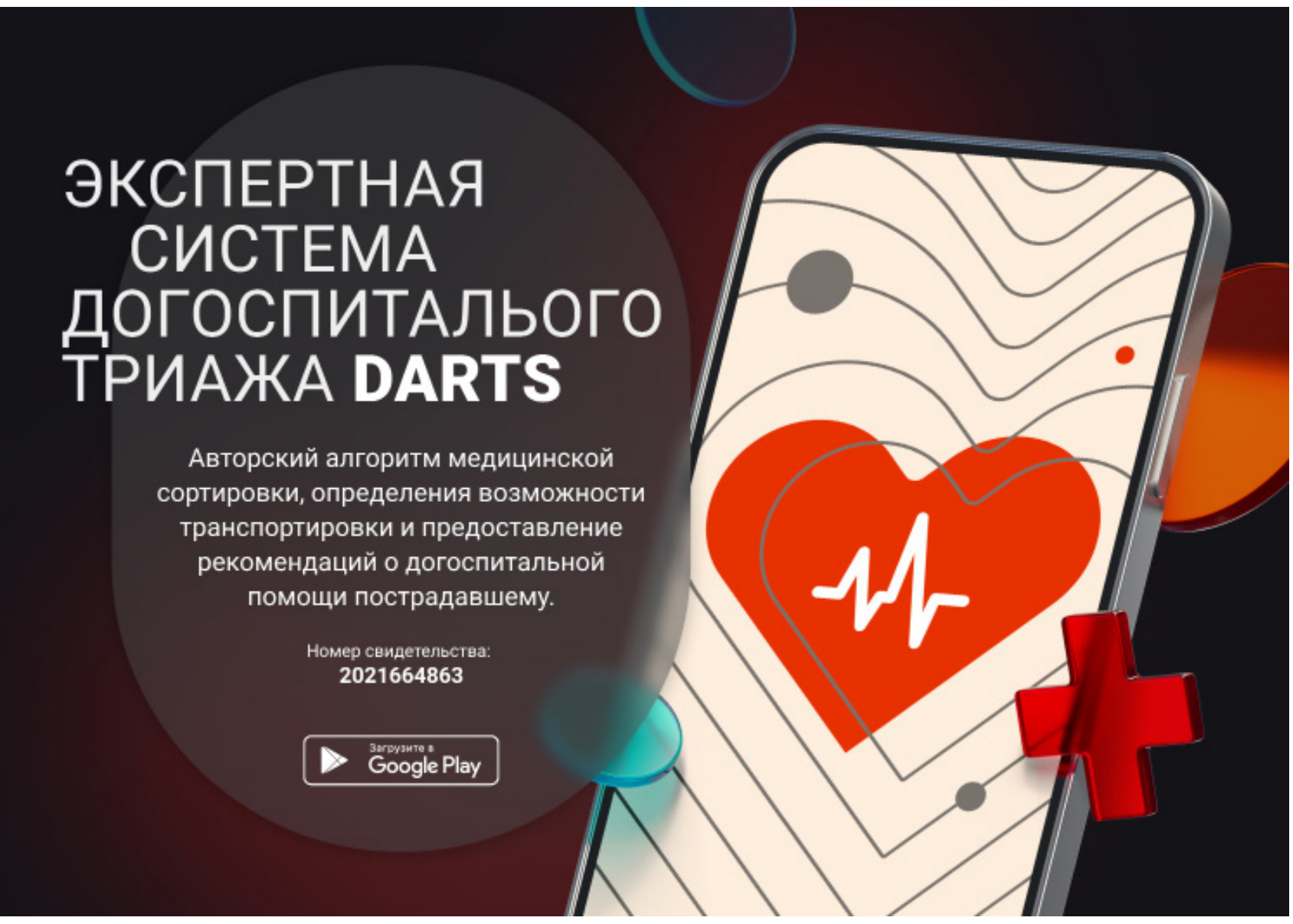